УДК 346.2

DOI https://doi.org/10.32844/2618-1258.2020.6-2.10

ЮДІН В.Ю.

\author{
ТРАНСФОРМАЦІЯ СУБ'ЄКТІВ ГОСПОДАРЮВАННЯ \\ В УМОВАХ ЦИФРОВІЗАЦЇ̈ ЕКОНОМІКИ
}

\title{
TRANSFORMATION OF BUSINESS ENTITIES IN THE CONTEXT OF DIGITALIZATION OF THE ECONOMY
}

Впровадження в життя будь-яких нових технологій, зокрема цифрових - процес, безумовно, тривалий і несе в собі масу невідомих ще викликів та небезпек для людства, але цифрові технології відкривають унікальні можливості для розвитку нашої економіки та підвищення якості життя громадян. Крім того, бурхливий розвиток цифрових технологій характеризує настання нового етапу промислової революції, який змінює зміст праці й життя людини. Масштабне впровадження таких технологій створює сприятливі передумови для загальних автоматизації та роботизації виробництва.

Останні десятиріччя характеризуються стрімким розвитком науки й техніки, розвиваються інформаційні технології та Інтернет, який вважають «четвертим каналом», що пов'язує людей між собою (після особистого спілкування, телефону та пошти). Цей зв'язок давно перестав бути лише невичерпним джерелом інформації, а $є$ доступним засобом комунікації. Інтернет із глобальної поштової та інформаційно-пошукової системи перетворився на інструмент ведення сучасного бізнесу, заснованого на принципах мережевої економіки.

Комунікаційні технології змінюють саму сутність бізнес-моделей - базових процесів створення продуктів і послуг виробниками та надання їх кінцевим споживачам. Крім того, поява цифрових технологій почала відкривати унікальні можливості щодо розвитку економіки та підвищення якості життя громадян, але зміни почнуть відбуватися тільки тоді, коли «цифрова» трансформація стане основою життєдіяльності суспільства, бізнесу та державних установ, а явище як цифровізація стане звичним та повсякденним.

Крім того, відмовляючись від паперових процесів та цифровізуючи складові елементи своєї роботи, суб'єкти господарювання зможуть зменшити кількість кроків, раніше необхідних для функціонування, поліпшити терміни виконання робіт, значно підвищити ефективність своєї діяльності та, в кінцевому підсумку, знизити експлуатаційні витрати.

Статтю присвячено складній проблемі - ролі держави, iї економіко-правової політики щодо цифровізації у сфері господарювання. Актуальність цієї проблеми пов'язана зі стрімким поширенням цифрових технологій у сфері господарювання, що позначилося на ключових видах господарських відносин. У статті розглянуто особливості трансформації суб'єктів господарювання в умовах цифровізації економіки, виокремлено види підприємств у сфері цифрової економіки, проаналізовано проблеми законодавчого врегулювання особливостей правового становища та відповідальності віртуальних підприємств.

Ключові слова: суб' 'кти господарювання, иифрова економіка, ичиррові технології, електронний бізнес, віртуальне підприємство.

(C ЮДІН В.Ю. - аспірант IV курсу за спеціальністю 081 «Право» (Інститут економіко-правових досліджень імені В.К. Мамутова Національної академії наук України) 
The introduction of any new technology, including digital - a process, of course, long and carries a lot of unknown challenges and dangers for humanity, but digital technology opens up unique opportunities for our economy and improving the quality of life of citizens. In addition, the rapid development of digital technologies characterizes the onset of a new stage of the industrial revolution, which changes the meaning of labor and human life. Large-scale implementation of such technologies creates favorable conditions for general automation and robotization of production.

The last decades have been characterized by the rapid development of science and technology, the development of information technology and the Internet, which is considered the "fourth channel" that connects people with each other (after personal communication, telephone and mail). This connection has long ceased to be just an inexhaustible source of information, but is an accessible means of communication. The Internet from a global mail and information retrieval system has become a tool for modern business based on the principles of network economy.

Communication technologies change the very essence of business models - the basic processes of creating products and services by manufacturers and providing them to end users. In addition, the advent of digital technologies has opened up unique opportunities for economic development and improving the quality of life of citizens, but change will occur only when the "digital" transformation becomes the basis of society, business and government agencies, and the phenomenon of digitalization becomes commonplace.

In addition, by abandoning paper processes and digitizing the components of their work, businesses will be able to reduce the number of steps previously required to operate, improve the timing of work, significantly increase the efficiency of their activities and, ultimately, reduce operating costs.

This article is devoted to a complex problem - the role of the state, its economic and legal policy on digitalization in the field of management. The urgency of this problem is relate to the rapid spread of digital technologies in the field of management, which has affected key types of economic relations. The article considers the peculiarities of the transformation of economic entities in the context of digitalization of the economy, identifies the types of enterprises in the digital economy, analyze the problems of legislative regulation of the legal status and responsibilities of virtual enterprises.

Key words: business entities, digital economy, digital technologies, e-business, virtual enterprise.

Постановка проблеми. Цифровізація остаточно змінила економічні відносини суб'єктів господарювання та набула значних обертів, що має впливати і на державну економічну політику, положення щодо якої (але без згадки про цифровізацію економічної сфери) закріплено в ГК [1, ст. 9-12].

Крім того, цифрові технології змінили суспільне життя, що позначилося і на правових його аспектах. Так, класичний склад правовідносин (суб'єкти, об'єкти, зміст правовідносин) в умовах цифровізації набуває досить своєрідного забарвлення, у зв'язку з чим виникає проблема кваліфікації нових суб'єктів (зокрема, віртуальних підприємств), визначення особливості договірних зв'язків та умов забезпечення економічної конкуренції, відповідальності тощо в нових умовах [2, с. 56].

Цифрова економіка, отримуючи популярність у всьому цивілізованому світі, водночас пропонує, а часто - навіть диктує нові правила для ведення бізнесу, зокрема, вона надає нові можливості суб'єктам господарювання.

Більшість вітчизняних підприємств у контексті розвитку значно відстають від зарубіжних, що певною мірою зумовлено відсутністю проведення своєчасних наукових досліджень, спрямованих на обгрунтування тенденцій, викликів, можливостей, котрі з'являються в процесі переходу до цифрової економіки. У цьому зв'язку переважна частина компаній змінює підходи до процесів формулювання цілей та окреслення мережі цінностей відповідно до вимог сучасності. Отже, це актуалізує проблематику цифровізації економіки як перспективного напряму розвитку для суб'єктів господарювання.

Аналіз останніх досліджень і публікацій. Огляд досліджень із цифровізації економіки України у науці господарського права показав, що вони представлені циклом статей О. Вінник. Для дослідження, проведеного у даній статті, $є$ важливим обгрунтування вченою своєї пропозиції 
про потребу відповідного правового регулювання суб'єктного складу відносин сфери цифрової економіки (представників е-бізнесу та їх саморегулівних організацій, споживачів, уповноважених органів); їхніх прав та обов'язків у сфері цифрової економіки, механізму захисту прав та законних інтересів, відповідальності за порушення у цій сфері та наслідків зловживання правами, особливостей розгляду конфліктів/спорів [2, с. 60].

Окремі питання правової проблематики цифрової економіки розглядали такі науковці як: А. Гавриленко, М. Кулинич, В. Кочин, Б. Тетерятник, О.В. Шаповалова, М. Дутов, М. Кучерявенко та інші.

Постановка завдання. Метою статті є дослідження трансформації суб’єктів господарювання в умовах цифровізації економіки.

Результати дослідження. Розвиток взаємовідносин у суспільному середовищі залежить від рівня розвитку економіки. Це стосується будь-якого рівня: глобального, національного, регіонального, територіального тощо. Цифровізація економіки являє собою певну економічну технологію зі своїми особливостями, тенденціями та закономірностями. Багато країн світу використовують дану технологію для підвищення ефективності розвитку економіки, зростання конкурентоспроможності тощо [3].

Крім того, цифровізація економіки - нове соціально економічне і техніко - технологічне явище, яке змінює реальність. Комп'ютери та інші цифрові досягнення стимулюють роботу мозку людини у напрямі кращого розуміння і подальшого формування нового, поліпшеного середовища життєдіяльності, розширення доступу до Інтернету допомагає робити все це швидше. Ці зміни впливають на людей у всьому світі, як у побуті, так і на виробництві [4].

У схваленій урядовій Концепції розвитку цифрової економіки та суспільства України на 2018-2020 роки цифровізація розглядається як насичення фізичного світу електронно-цифровими пристроями, засобами, системами та налагодження електронно-комунікаційного обміну між ними, що фактично уможливлює інтегральну взаємодію віртуального та фізичного, тобто створює кіберфізичний простір [5].

В. Ляшенко та О. Вишневський розглядають процес цифровізації з позиції поділу економіки на три сектори (первинний - сільське господарство і видобуток корисних копалин, вторинний - промислове виробництво, третинний - послуги), то принциповою відмінністю $є$ не стільки збільшення частки третинного сектора або появи та розширення нового (цифрової економіки), а радикальне перетворення всіх трьох вже існуючих секторів [6, с. 8]. Позиція наведених науковців тісно корелює з ідеями закладеними К. Кларком та Ж. Фурастьє [7] у теорії постіндустріального суспільства, в якій поділ суспільного виробництва також ділився на три сектори за схожим принципом, науковці наголошували, що в майбутньому стрімко зростатиме частка третинного сектора економіки (сфера послуг) порівняно із сільським господарством та промисловістю.

Водночас цифровізація зумовлює встановлення обладнання, програм та послуг, розроблення нових продуктів та діючих моделей (аналогові процеси повинні бути замінені цифровими), але насамперед компанії повинні інвестувати у грамотних працівників, щоб система IT дійсно становилася основою інфраструктури компанії. Це, зі свого боку, потребує від працівників використовувати право на самостійні рішення, що повинно стимулюватися заохочувальними системами. Тому необхідне інвестування в інтелектуальний капітал компанії [8].

Вважається, що цифрові технології є інструментом та засобом для інших видів господарської діяльності, за допомогою яких можна ефективно модернізувати виробництво або ж надавати послуги, а також окремим ринком або галуззю господарської діяльності.

Крім того, цифрові технології стали базою для створення нових продуктів, цінностей, властивостей та, відповідно, основою отримання конкурентних переваг на більшості ринків.

Суб’єкти господарювання, які мають на меті перейти на «цифрові» рейки повинні фокусуватися на автоматизації виробничих та управлінських процесів, з метою підвищення ефективності функціонування. Підприємство, яке робить акцент на «цифровізації», повинно націлюватися на дієву віддачу від цих процесів, через більш високу залученість співробітників до прийняття управлінських рішень.

Але «Цифровізацію» варто розглядати як інструмент, а не як самоціль. При системному державному підході «цифрові» технології будуть значно стимулювати розвиток відкритого інформаційного суспільства як одного з істотних факторів розвитку демократії в Україні, підвищення продуктивності, економічного зростання, створення робочих місць, а також підвищення якості життя громадян України [9]. 
У нашій країні 17 січня 2018 року Кабінет Міністрів України схвалив «Концепцію розвитку цифрової економіки та суспільства України на 2018-2020 роки». Вона передбачає здійснення заходів щодо впровадження відповідних стимулів для цифровізації економіки, усвідомлення наявних викликів та оволодіння інструментами розвитку цифрових інфраструктур, визначає критичні сфери та проекти цифровізації, а також - стимулювання внутрішнього ринку виробництва, використання та споживання цифрових технологій [4].

Запровадження зазначеної Концепції передбачає набуття суб’єктами господарювання цифрових компетенцій, а також відповідного правового опосередкування їх поведінки під час користування платформою «Уряд для бізнесу» [11].

Відповідно до ст. 2 Господарського кодексу України (далі - ГК України) учасниками відносин у сфері господарювання є суб'єкти господарювання, споживачі, органи державної влади та органи місцевого самоврядування, наділені господарською компетенцією, а також громадяни, громадські та інші організації, які виступають засновниками суб'єктів господарювання чи здійснюють щодо них організаційно-господарські повноваження на основі відносин власності [1].

Водночас суб'єктами господарювання визнаються учасники господарських відносин, які здійснюють господарську діяльність, реалізуючи господарську компетенцію (сукупність господарських прав та обов'язків), мають відокремлене майно і несуть відповідальність за своїми зобов'язаннями в межах цього майна, крім випадків, передбачених законодавством (ст. 55 ГК України).

Цифрова економіка та іiї складник - електронний бізнес мають низку специфічних ознак, зумовлених використанням інформаційно-комунікаційних (і в першу чергу - цифрових) технологій для комунікації іiї учасників, завдяки чому така економічна система отримала назву цифрової [4]. Зокрема, це стосується суб'єктного складу, в якому, крім традиційних учасників господарських відносин (суб'єктів господарювання зі статусом індивідуального підприємця або юридичної особи, споживачів-громадян та суб'єктів організаційно-господарських повноважень, створених як юридичні особи, в тому числі - як уповноважені органи), наявні віртуальні підприємства [11] як група фізичних та/або юридичних осіб, яка нерідко використовує один електронний ресурс - електронний магазин чи електронну торговельну платформу, але без оформлення організаційної єдності такої групи в якості юридичної особи. В об'єктному складі домінують об'єкти, що не мають речової форми, - номерний та радіоресурси, мережа Інтернет, вебсайти, зокрема інтернет-магазини, інтернет-платформи тощо) [12, с. 127].

Цифровізація виробничих чи управлінських процесів не обмежується звичайною автоматизацією внутрішніх процесів підприємства, оскільки передбачає переведення частини роботи персоналу на програмне забезпечення. За рахунок цифровізації робочих процесів підприємства зменшують кількість дій, необхідних для виконання завдань, скорочується паперова робота, значно зменшується кількість помилок та підвищується продуктивність праці персоналу. Збереження звичайних алгоритмів роботи в незмінному вигляді може призвести до відставання від конкурентів, яке ліквідувати у подальшому буде дуже проблематичним [13].

Крім того, цифровізація промислового виробництва має на увазі інтеграцію низки проривних технологій: віртуального моделювання, Інтернету речей, робототехніки, штучного інтелекту, великих даних, технологій хмарних і граничних обчислень, предикативної аналітики, нових стандартів зв'язку та ін.

На підставі вищевикладеного можна зробити висновок, що розвиток цифрових технологій значно вплинув на організацію господарської діяльності та суспільні відносини, які виникають у цифровому середовищі.

Крім того, можна наголосити на тому, що цифрові технології відіграють дуже важливу роль в процесі виробництва, підході до ведення підприємництва та підприємницької діяльності. Питома вага суспільних відносин, пов'язаних із використанням комп'ютерних мереж у господарській діяльності, розповсюдилася всім світом і передбачає потребу забезпечення ефективної правової регламентації вказаних відносин.

Цифрова трансформація для кожного суб'єкта господарювання це - зміна організаційної культури і впровадження нових цифрових технологій та комунікацій, які розширюють можливості і дозволяють формувати власну так звану «екосистему» у взаємодії зі своїми контактними аудиторіями [14]. Така трансформація виявляється як на зовнішньому рівні взаємодії - між підприємствами, так і у середині кожного окремого підприємства - на рівні відносин між працівниками. Т. Подчасова, вважає, що «підприємство сьогодні - це не просто сукупність процесів бізнесу 3 жорсткою структурою, коефіцієнт корисної дії яких необхідно підвищувати. Мета сьогоднішніх економічних перетворень - це зміна самої моделі підприємства» [15]. 
Цифрова трансформація здійснюється в різних площинах організації. Змінюються технології та бізнес-процеси побудовані на них, що в свою чергу, призводить до модифікації структури, системи управління і культури організацій [16]. Цифрова трансформація бізнесу - це організаційні зміни за рахунок використання цифрових технологій і бізнес-моделей для підвищення продуктивності. Як основу цифрової трансформації, яка визначає фокус перетворень та цільовий рівень цифрової зрілості підприємства, Т. Гілєва розглядає стратегію. Інструментами деталізації і реалізації стратегії $є$ бізнес-модель, дорожня карта і портфель проектів, збалансований з позицій реалізації технологічних і нетехнологічних інновацій, спрямованих на зростання цифрової зрілості підприємства [17].

Сучасні цифрові тенденції в економіці стали підгрунтям для виокремлення підприємств наступних типів:

1. Підприємства традиційного складу, суб'єкти підприємницької діяльності - юридичні (фізичні) особи, які ведуть свій бізнес і використовують активи в реальній фізичній матеріальній, нематеріальній чи фінансовій формі. Такі підприємства використовують у своїй господарській діяльності елементи цифровізації, проте вони не є цифровими [18, с. 9$]$.

Традиційні підприємства (середні і великі), в прагненні протистояти сучасним викликам, впроваджують цифрові технології. Їх уміння перебудуватися на цифровий ландшафт $є$ найважливішою конкурентною перевагою. Проте для малих підприємств традиційного складу все, що пов'язане із автоматизацією та інформаційними рішеннями, є дорогим та не настільки необхідним у силу ручного управління [18, с. 10$]$.

2. Частково віртуальні підприємства, суб'єкти підприємницької діяльності - юридичні (фізичні) особи, які можуть мати фізичні матеріальні, нематеріальні чи фінансові активи, проте способи просування цих активів у цих підприємств віртуальні, цифрові. Як правило, такі підприємства, маючи запаси товарів, вбачають найоптимальніший шлях їх просування до клієнта тільки через мережу Інтернет. Ці підприємства більшою мірою ніж традиційні інтегровані в цифрову економіку, оскільки Інтернет - це основний канал їх продажів, місце, де вони генерують виручку. Відповідно способи просування своєї продукції і канали реклами у цих підприємств теж віртуальні, цифрові [18, с. 10].

3. Віртуальні підприємства, умовні організаційні структури, мережеве існування яких, складається з неоднорідних агентів, що взаємодіють в комп'ютерно-опосередкованому середовищі і розташовані у різних місцях.

Віртуальне підприємство - це нова, якісно вища форма організації підприємства, яка замінить фізичну структуру комунікативними технологіями, основною метою якого $є$ швидка адаптація до вимог ринку, максимальне використання інтернет-ресурсів. Впроваджуючи інноваційні рішення, віртуальне підприємство матиме можливість оптимізувати бізнес-процеси, скоротити витрати, і знайти нові джерела доходів. [18, с. 10].

Проте здійснювати свою діяльність задля досягнення основної мети - отримання прибутку - вітчизняне віртуальне підприємство зможе тільки набуваючи статусу юридичної особи, тобто здійснивши усі правові чинні процедури. Тобто є ряд ознак, які є спільними і одночасно відрізняють віртуальне підприємство (віртуальну організацію), від інших вітчизняних суб'єктів господарської діяльності у набутті статусу юридичної особи.

А. Гавриленко звертає увагу на те, що поступово і юридична особа вже пересувається у віртуальний простір. Так, реєстраційна служба на сьогодні провадить зберігання реєстраційних документів юридичних осіб в електронній формі, що ставить під питання необхідність збереження статутних документів в паперовій формі, з якими ми маємо можливість ознайомитись за допомогою електронних сервісів. Однак здійснити державну реєстрацію юридичної особи без зазначення поштового місцезнаходження на сьогодні є неможливим [19].

Звичайно, відсутність реальної адреси, на перший погляд може призвести до низки проблем, зокрема юридична адреса важлива для визначення місця укладення договору відповідно до положень ст. 647 Цивільного Кодексу України (далі - ЦК) [20], місця виконання зобов’язання відповідно до положень ст. 532 ЦК України, вона має значення при визначенні підсудності спору, визначення органу, до якого необхідно сплачувати податки, постає відповідно й питання можливого притягнення до відповідальності осіб, які ведуть таку діяльність [20]. У сучасних умовах як місцезнаходження, так і ведення діяльності юридичної особи може бути перенесено до всесвітньої мережі. Водночас для осіб, які мають на меті здійснення підприємницької діяльності, актуальною є можливість провадження такої діяльності у формі юридичної особи. Це дає можливість обмежити відповідальність за зобов'язаннями, які виникають під час здійснення такої діяльності, майном юридичної особи, що робить актуальним розроблення та формулювання поняття віртуальної юридичної особи [20]. 
Суб’єкти господарювання у сфері цифрової економіки мають такі особливості: ління [21];

- використання новітніх інформаційних технологій та централізованої системи управбою [22];

- мобільність, відсутність тісного фізичного контакту структурних підрозділів між со-

- розмиті межі віртуальних організацій, об’єднують постачальників, дистриб'юторів, клієнтів у ланцюги поставок, що не мають меж [22];

- інтеграція кращих технологій, засобів виробництва й досвіду агентів віртуального підприємства, їх об'єднання навколо ключових бізнес-процесів [21;23];

- гнучкість і відповідна реакція, (наприклад, віртуальні підприємства можуть створюватися із окремих елементів для реалізації певної і мети і розпадатися після її досягнення) [24];

- накопичення ресурсів навколо ключових бізнес-процесів [22], незначна фізична структура і висока віртуальна наявність активів (мережеві об'єднання); [21];

- розроблення неоднорідних комп’ютерних мереж і середовищ, застосування різноманітних програмних засобів, використання інформаційних і комунікаційних технологій для динамічного зв'язку людей і активів [21; 22];

- саморегулювання та самоорганізація, координація та взаємодія на основі раніше оговореного з партнерами управління бізнес-процесами та ресурсами [25].

- максимізації прибутку у віртуальному просторі цифрової економіки на основі капіталізації знань, процесів.

Відносини між суб'єктами цифрової економіки, включно з договірними зв'язками, зазвичай встановлюються також з використанням електронних засобів, які, в свою чергу, можуть застосовуватися при врегулюванні/вирішенні між цими особами конфліктів/спорів. Зазначені обставини зумовлюють і певну специфіку відповідальності у сфері цифрової економіки, проте в законодавстві України відсутні уніфіковані положення з цього питання через розпорошеність норм, які регулюють відносини в цій сфері в численних актах законодавства, або відсутність важливих положень, пов'язаних з відповідальністю учасників відносин щодо використання електронних бізнес-ресурсів на зразок згаданих сайтів - інтернет-магазинів та торговельних інтернет-платформ [12, с. 127].

О. Вінник наголошує насамперед, на прогалинах в законодавстві щодо особливостей правового становища та відповідальності віртуальних підприємств, які зазвичай уникають необхідної для функціонування у сфері економіки легалізації (попри ії наявності в усіх або частини учасників таких підприємств), а також фактичних користувачів таких ресурсів/сайтів (інтернет-магазини тощо) [12, с. 127] за недотримання вимог законодавства щодо розкриття інформації, передбаченої законами «Про електронну комерцію» [26] та «Про захист прав споживачів» [27].

Так, законодавець: не визначає більш-менш грунтовно правовий режим інтернет-магазинів як сайтів, користуючись іншим поняттям - інтернет-магазин як засіб для представлення або реалізації товару, роботи чи послуги шляхом вчинення електронного правочину (ст. 3 ЗУ «Про електронну комерцію»); відсутність універсального (щодо всіх видів послуг у сфері цифрової економіки) поняття «власник сайту» та «фактичний користувач сайту» (наявне в підзаконних актах поняття власника сайту як його користувача [28] навряд чи коректне, адже сайт може передаватися власником в користування іншим особам; до того ж воно стосується сфери надання лише електронних довірчих послуг, що відрізняється від сфери електронної комерції, в якій один сайт може використовуватися кількома чи навіть багатьма особами (зокрема, учасниками одного чи кількох віртуальних підприємств); суб'єктами електронної комерції законодавець визначає продавця (виконавця, постачальника) товарів, робіт, послуг (ст. 7 ЗУ «Про електронну комерцію»), покупця (замовника, споживача) товарів, робіт, послуг (ст. 8 ЗУ «Про електронну комерцію»), постачальника послуг проміжного характеру (ст. 9 3У «Про електронну комерцію») ; не враховує при цьому важливі обставини, а саме, що: а) при використанні такого сайту, як інтернет-магазин, нерідко важко визначити фактичного продавця, оскільки інформація подається з сайту, що перебуває у користуванні різних продавців без зазначення, які товари кожен з них пропонує до продажу та продає; б) в укладеному із споживачем електронному договорі (е-договорі) також така інформація нерідко відсутня, а в підсумку - непросто визначити, яка особа має нести відповідальність за не розкриття передбаченої законом інформації та порушення інших прав споживачів [12, с. 127].

Можна погодитися з Б. Тетерятником, який зауважує про певну відірваність держави від упровадження зазначених технологій у сферу господарювання свідчить той факт, що запровадження нових сучасних інформаційно-комунікаційних технологій і рішень щодо створення ін- 
формаційних ресурсів і запровадження електронних технологій для підвищення конкурентоспроможності здійснюються сьогодні переважно самими суб'єктами господарювання [29, с. 66].

Насамперед треба зауважити, що цифрова трансформація суб'єктів господарювання повинна забезпечувати впровадження заходів щодо управління ризиками і навчати працівників для забезпечення високого рівня конфіденційності та безпеки, також можна побачити, що зростаюча взаємодія (взаємодоповнюваність) між працівниками та ІКТ зумовлює нові підходи до організації роботи, що може збільшити обсяги виробництва.

Висновки. Сьогодні цифрові технології кардинально змінюють усталені державні та громадські інститути, зумовлюють трансформацію права в цифрову епоху, змінюють систему суспільно-економічних відносин, так і всієї інституційної структури суспільства.

Підвищення швидкості та розповсюдження широкосмугового доступу до Інтернет зв’язку, формують нові види бізнесу, які прийнято називати віртуальними, інформаційними, цифровими та мережевими. Однак протягом останніх десяти років тенденції віртуального бізнесу змінилися від часткового продовження бізнес-моделі у внутрішній підприємницькій мережі до повного охоплення бізнес-моделей світовою Інтернет мережею, яка викликала появу інформаційних посередників та інших суб'єктів, статус яких також потребує корекції в господарському праві.

Крім того, вищевказаний бізнес ще не став переважаючим, хоча його елементами пронизана майже вся підприємницька діяльність та функціонування ії суб'єктів, а також в рамках даного факту господарські відносини зазнають істотних змін. Зокрема, з'явилися нові складники таких відносин - віртуальні підприємства та віртуальні об'єкти, електронна форма зв'язків, включаючи договори.

Треба звернути увагу на те, що динамічнішим із компонентів процесу цифровізації є правовідносини між суб' єктами, які вже були визнані на законодавчому рівні, одним із прикладів даного факту $є$ те, що в рамках чинного законодавства відбувається укладення договорів але насправді діючі нормативно-правові акти ще не в змозі охопити всі правовідносини, що виникають та стрімко розвиваються в умовах цифровізації.

Притаманна для згаданих суб'єктів та об'єктів віртуальність та пов'язані з цим ризики свідчать про необхідність відображення на рівні законодавства специфіки господарських відносин в умовах цифровізації з метою впорядкування функціонування віртуальних підприємств та використання електронних ресурсів для забезпечення соціального спрямування цих відносин. Зволікання з таким регулюванням загрожує значними ризиками, які притаманні для цифровізації нарівні з ії перевагами.

Отже, сучасний стан господарсько-правового регулювання досліджуваної сфери в Україні може бути відзначений як такий, що перебуває на стадії становлення загальних уявлень про механізми правового забезпечення відповідних трансформаційних процесів і характеризується, на жаль, уповільненими темпами реального законодавчого супроводу пов'язаних із ними змін у сфері господарювання.

\section{Список використаних джерел:}

1. Господарський кодекс України від 16 січня 2003 року № 436-IV. Офіційний портал Верховної Ради України. URL: https://zakon.rada.gov.ua/laws/show/436-15\#Text (дата звернення: 04.02.2021).

2. Вінник О.М. Господарські відносини в умовах цифровізації та їх правове регулювання. Підприємниитвво, господарство і право. 2020. № 5. С. 56-62.

3. Сєнкевич О.Ф. Трансформація територіально - економічних систем в умовах розвитку цифрової економіки та суспільства. Дисертаиія. 2020. С.18.

4. Цифровізація економіки України: трансформаційний потенціал: монографія / В.П. Вишневський, О.М. Гаркушенко, С.І. Князєв, Д.В. Липницький, В.Д. Чекіна; Інститут економіки промисловості НАН України, 2020. С. 35.

5. Про схвалення Концепції розвитку цифрової економіки та суспільства України на 20182020 роки та затвердження плану заходів щодо ії реалізації: Розпорядження Кабінету Міністрів України від 17 січня 2018 р. № 67-p. URL: http://zakon5.rada.gov.ua/laws/show/67-2018-p/page (дата звернення: 04.02.2021).

6. Ляшенко В.І. Цифрова модернізація економіки України як можливість проривного розвитку: монографія / В.І. Ляшенко, О.С. Вишневський; НАН України, Ін-т економіки пром-сті. K., 2018. 252 c.

7. Clarck C. Conditions of economic progress. 3-d ed. / C. Clarck. London: The Macmillian Co. New York: St. Martin's press, 1957. 236 p. 
8. Tetiana Bludova, Tetiana Galakhova, Volodymyr Tokar. Analysis of innovation security threat to the machine-building industry: collective monograph. Volume 4. Socio-economic reforms of the national economy recovery: the experience of Ukraine. Bydgoszcz. 2018. P. 179-208 / Edited by Olexandr Vlasiuk et al. Vol. 4. Bydgoszcz, Poland: University of Economy Publishing, 2018. 355 p.

9. Цифрова адженда України - 2020 (проект) («Цифровий порядок денний» - 2020) Концептуальні засади (версія 1.0) Першочергові сфери, ініціативи, проекти «цифровізації» України до 2020 року. Грудень, 2016. URL: https://ucci.org.ua/uploads/files/58e78ee3c3922.pdf (дата звернення: 04.02.2021).

10. Шаповалова О. В. Цифрова платформа електронного адміністрування податку на додану вартість. Право та інноваційне суспільство. 2018. № 2. С. 23-30.

11. Поняття віртуального підприємства. URL: http://www.ukr.vipreshebnik.ru/economikapidpr/2558-ponyattya-virtualnogo-pidpriemstva.html (дата звернення: 04.02.2021).

12. Вінник О. М. Господарсько-правова відповідальність та процедури ії застосування у сфері цифрової економіки та електронного бізнесу. Приватне право і підприємництво. 2020. Вип. 20. С. 126-137.

13. Руденко М.В. Цифровізація економіки : Нові можливості та перспективи. Економічна наука. 2018. Вип. 11. С. 61-65.

14. Кокорев А.С. Цифровая экономика: смена ценностей и ориентиров в управлении предприятием. Московский экономический журнал. 2019. № 1. С. 252-259.

15. Подчасова Т.П. Віртуальні підприємства як сучасна форма організації виробництва. Економіко-математичне моделювання сочіально-економічних систем: збірник наукових праць МННЦ ІТіС. Київ. 2009. Вип. 14. С. 24-45

16. И.А. Аренков, С.А. Смирнов, Д.Р. Шарафутдинов, Д.В. Ябурова. Трансформация системы управления предприятием при переходе к цифровой экономике. Российское предпринимательство. 2018. № 5. С. 1711-1722. URL: https://cyberleninka.ru/article/n/transformatsiyasistemyupravleniya predpriyatiem-pri-perehode-k-tsifrovoy-ekonomike.

17. Гилева Т.А. Цифровая зрелость предприятия: методы оценки и управления. Вестник УГНТУ. Наука, образование, экономика. Серия: Экономика. 2019. № 1 (27). С. 38-52 [Електронний ресурс]. - Режим доступу: https://cyberleninka.ru/article/n/tsifrovaya-zrelost-predpriyatiyametody-otsenki-i-upravleniya.

18. Кулинич М.Б. Цифрова трансформація вітчизняних підприємств в сучасних умовах. Економіка, управління та адміністрування. 2019. № 3 (89). 2019. С. 8-15.

19. Гавриленко А.І. Щодо правової природи віртуальних організацій та можливості існування віртуальних юридичних осіб. IT право: проблеми і перспективи розвитку в Україні (Друга міжнародна щорічна конференція) URL: http://aphd.ua/publication-361(дата звернення: 04.02.2021).

20. Цивільний кодекс України від 16 січня 2003 року № 435-IV. Офіційний портал Верховної Ради України. URL: https://zakon.rada.gov.ua/laws/show/435-15\#Text (дата звернення: 04.02.2021).

21. Танасійчук В. Особливості віртуальних підприємств Вісник КНTЕУ. URL: http://visnik.knteu.kiev.ua/files/2009/06/14.pdf. (дата звернення: 04.02.2021).

22. Кокорев А.С. Цифровая экономика: смена ценностей и ориентирование в управлении предприятием. Московский экономический журнал. 2019. № 1. С. 252-259.

23. Подчасова Т.П. Віртуальні підприємства як сучасна форма організації виробництва. Економіко-математичне моделювання сочіально-економічних систем: збірник наукових праиь МННЦ ITіС. Київ. 2009. Вип. 14. С. 24-45.

24. Коблова Ю.А. Виртуальные организации как новейшая форма сетевых структур. URL: https://cyberleninka.ru/article/n/virtualnye-organizatsii-kak-noveyshaya-formasetevyh-struktur (дата звернення: 04.02.2021).

25. Падерін І.Д., Романов О.В., Савельєв І. В. Віртуальне підприємство як резерв підвищення ефективності у нових умовах. Вісник економічної науки України. 2014. № 3 (27). С. 85-88. 26. Про електронну комерцію: Закон України від 3 вересня 2015 р. Відомості Верховної Ради України. 2015. № 45. Ст. 410.

27. Про захист прав споживачів: Закон України від 12 травня 1991 р. Відомості Верховної Ради УРСР. 1991. № 30. Ст. 379.

28. Вимоги у сфері електронних довірчих послуг: затв. постановою Кабінету Міністрів України від 7 листопада 2018 p. № 992. URL: https://zakon.rada.gov.ua/laws/show/992-2018-\% D0\%BF (дата звернення: 04.02.2021).

29. Тетерятник Б. Віртуалізація господарської діяльності: сутність і загальні засади правового регулювання в Україні. Підприємництво, господарство і право. 2017. № 11. С. 64-69. 